\title{
Application of Circuit Model for Photovoltaic Energy Conversion System
}

\author{
Natarajan Pandiarajan, Ramabadran Ramaprabha, and Ranganath Muthu \\ Department of Electrical \& Electronics Engineering, SSN College of Engineering, Kalavakkam 603110, India \\ Correspondence should be addressed to Natarajan Pandiarajan, pandiarajann@ssn.edu.in
}

Received 15 August 2011; Revised 11 November 2011; Accepted 15 November 2011

Academic Editor: Songyuan Dai

Copyright ( $) 2012$ Natarajan Pandiarajan et al. This is an open access article distributed under the Creative Commons Attribution License, which permits unrestricted use, distribution, and reproduction in any medium, provided the original work is properly cited.

Circuit model of photovoltaic (PV) module is presented in this paper that can be used as a common platform by material scientists and power electronic circuit designers to develop better PV power plant. Detailed modeling procedure for the circuit model with numerical dimensions is presented using power system blockset of MATLAB/Simulink. The developed model is integrated with DC-DC boost converter with closed-loop control of maximum power point tracking (MPPT) algorithm. Simulation results are validated with the experimental setup.

\section{Introduction}

The field of photovoltaics (PV) has experienced a remarkable growth for past two decades in its widespread use from standalone to utility interactive PV systems. The best way to utilize the electric energy produced by the PV array is to deliver it to the AC mains directly, without using battery banks [1].

A recent study in Germany, of $21 \mathrm{PV}$ systems in operation for 10 years, revealed that inverters contributed for $63 \%$ of failures, modules $15 \%$, and other components $23 \%$, with a failure occurring, on an average, every 4.5 years [2]. To reduce the failure rate of PV systems, it is necessary to reduce the failure rate of inverters and components also called the PV balance of systems (BOSs) that would result in their economic viability.

At present, PV BOS research uses mathematical functional models for the performance analysis of newly developed systems. These developed systems could not be readily adopted by the field professionals and hence the above failure rate. Hence the need for simplified Simulink modeling of PV module has been long felt.

Simple circuit-based PV models have been proposed in the literature [3-12]. Some authors have proposed indirect methods to adjust the $I-V$ curve through artificial intelligence $[13,14]$. Although interesting, such methods are impractical, complicated and require high computational effort. In all the above, modeling was limited to simulation of PV module characteristics.

In this paper, the design of PV system using simple circuit model with detailed circuit modeling of PV module is presented. In Section 2, the physical equations governing the PV module (also applicable to PV cell) are presented. Simulink model for each equation is presented with numerical results for different values of irradiation and temperature. The tabulation of the above numerical results gives the relationship of module parameters with characteristics curves of PV module, which are the indicators of circuit performance. In Section 3, complete circuit model is evolved after due experimental verification. In Section 4, modeling of MPPT using perturb and observe $(\mathrm{P} \& \mathrm{O})$ algorithm is carried out using Simulink. The operation of developed circuit model with DC to DC boost converter for closedloop MPPT control is verified with simulation. Section 5 presents the experimental verification of simulation results. In Section 6 result and discussions are presented.

\section{Modeling of PV Module}

2.1. Equivalent Circuit. A PV module consists of a number of solar cells connected in series and parallel to obtain the 


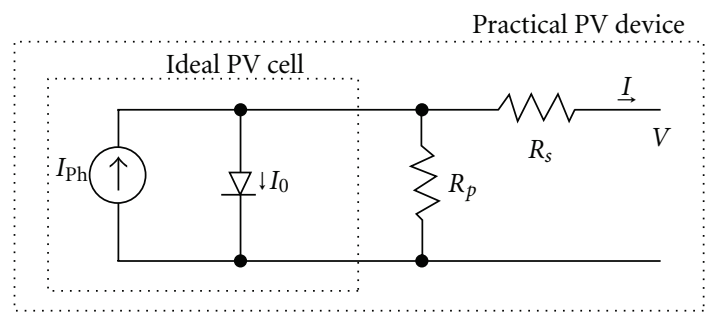

FIgURE 1: PV cell modeled as diode circuit.

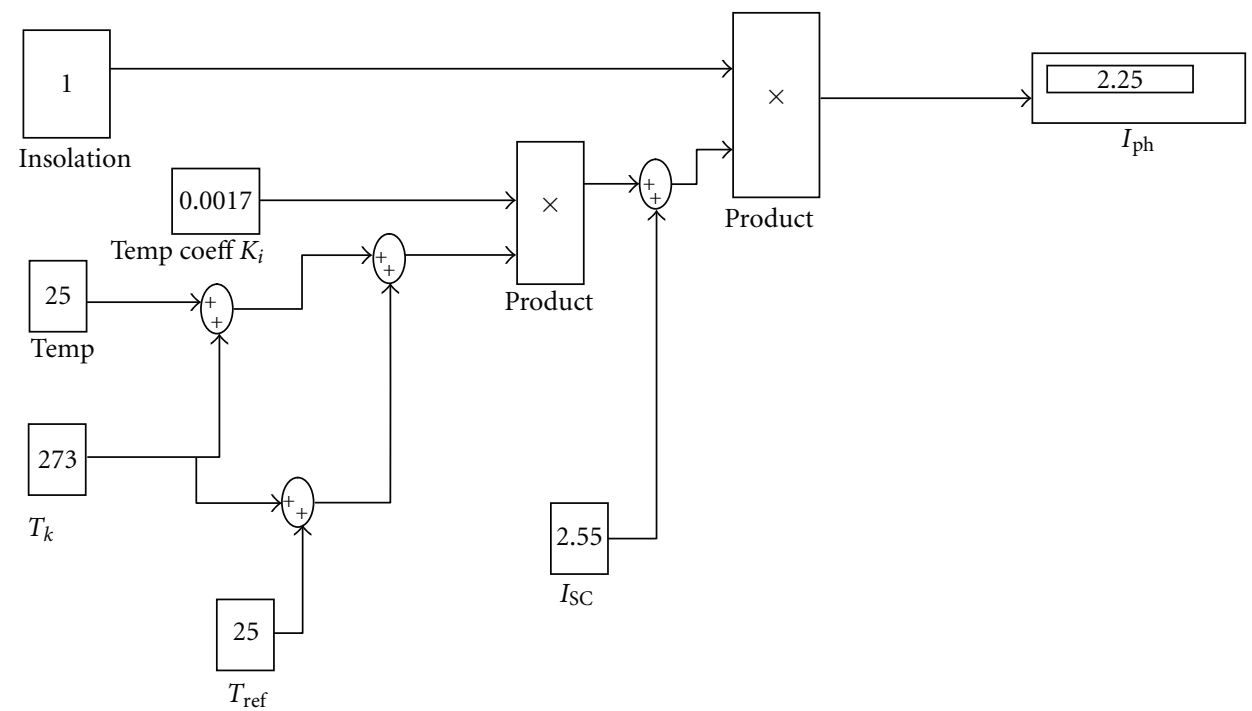

Figure 2: Photocurrent.

desired voltage and current output levels. Each solar cell is basically a p-n diode. As sunlight strikes a solar cell, the incident energy is converted directly into electrical energy without any mechanical effort.

Transmitted light is absorbed within the semiconductor, by using this light energy to excite free electrons from a low energy status to an unoccupied higher energy level. When a solar cell is illuminated, excess electron-hole pairs are generated throughout the material, hence the $\mathrm{p}-\mathrm{n}$ junction is electrically shorted and current flows.

For simplicity, the single-diode model of Figure 1 is used in this paper [15]. This model offers a good compromise between simplicity and accuracy with the basic structure consisting of a current source and a parallel diode. In Figure $1, I_{\mathrm{ph}}$ represents the cell photocurrent while $R_{\mathrm{sh}}$ and $R_{s}$ are, respectively, the intrinsic shunt and series resistances of the cell.

2.2. Equations of $P V$ Module. $P V$ cells are grouped in larger units called PV modules, which are further interconnected in a series-parallel configuration to form PV arrays.

The following are the basic equations from the theory of semiconductors and photovoltaics [15] that mathematically describe the $I-V$ characteristic of the photovoltaic cell and module.

2.3. Photocurrent. In Figure 1, the module photocurrent $I_{\mathrm{ph}}$ of the photovoltaic module depends linearly on the solar irradiation and is also influenced by the temperature according to the following equation:

$$
I_{\mathrm{ph}}=\left[I_{\mathrm{SCr}}+K_{i}\left(T_{k}-T_{\mathrm{ref}}\right)\right] * \frac{\lambda}{1000},
$$

where $I_{\mathrm{ph}}[\mathrm{A}]$ is the light-generated current at the nominal condition $\left(25^{\circ} \mathrm{C}\right.$ and $\left.1000 \mathrm{~W} / \mathrm{m}^{2}\right), K_{i}$ is the short-circuit current/temperature coefficient $(0.0017 \mathrm{~A} / \mathrm{K}), T_{k}$ and $T_{\text {ref }}$ are, respectively, the actual and reference temperatures in $K, \lambda$ is the irradiation on the device surface $\left(\mathrm{W} / \mathrm{m}^{2}\right)$, and the nominal irradiation is $1000 \mathrm{~W} / \mathrm{m}^{2}$.

Detailed Simulink model of (1) of photocurrent $I_{\mathrm{ph}}$ is shown in Figure 2. The value of module short-circuit current is $I_{\mathrm{SCr}}$ taken from the datasheet of the reference model as given in Section 2.4.

$I_{\mathrm{ph}}$ for different values of insolation and temperature is shown in Table 1. 


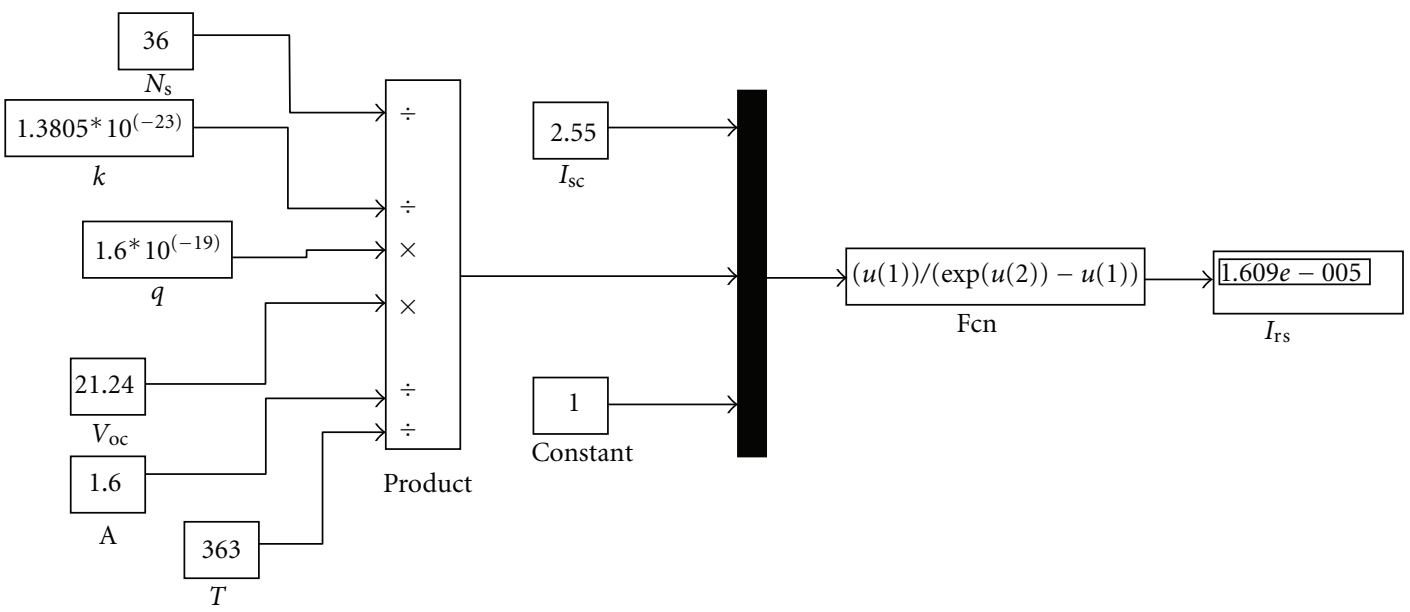

Figure 3: Module reverse saturation current.

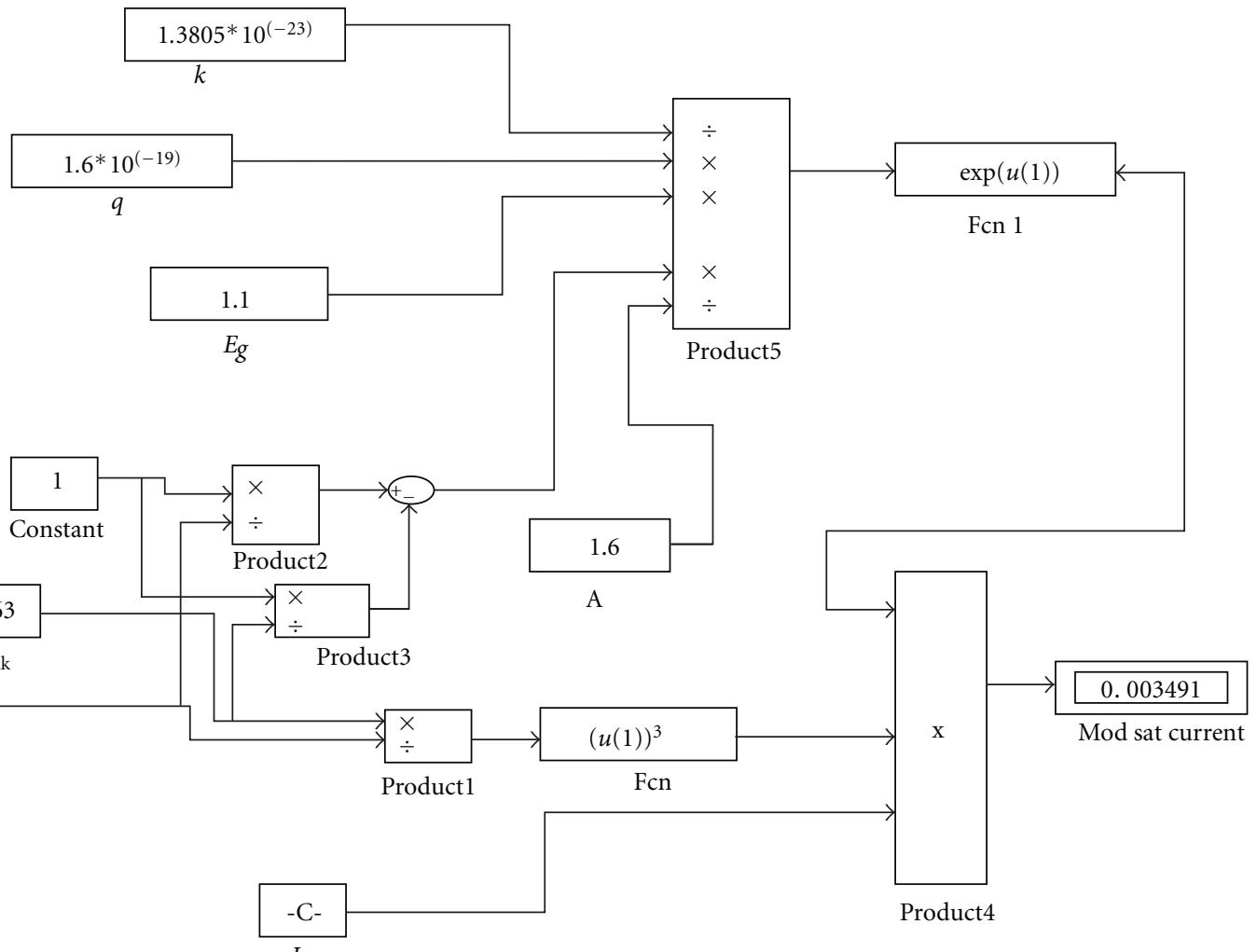

FIGURE 4: Module saturation current.

TABLE 1: $I_{\mathrm{ph}}$ for various insolations and temperatures.

\begin{tabular}{lcccccc}
\hline \multirow{2}{*}{ S. no. Insol W/m $/ \mathrm{m}^{2}$} & \multicolumn{5}{c}{ Value of $I_{\text {ph }}(\mathrm{A})$} \\
& & $25^{\circ} \mathrm{C}$ & $30^{\circ} \mathrm{C}$ & $40^{\circ} \mathrm{C}$ & $50^{\circ} \mathrm{C}$ & $90^{\circ} \mathrm{C}$ \\
\hline 1 & 1000 & 2.55 & 2.559 & 2.575 & 2.592 & 2.66 \\
2 & 700 & 1.785 & 1.791 & 1.803 & 1.815 & 1.862 \\
3 & 500 & 1.275 & 1.279 & 1.288 & 1.296 & 1.33 \\
4 & 250 & 0.6375 & 0.6396 & 0.6489 & 0.6481 & 0.6651 \\
5 & 100 & 0.255 & 0.2559 & 0.2576 & 0.2592 & 0.2661 \\
\hline
\end{tabular}

2.4. Reference Model. Solkar make $36 \mathrm{~W}$ PV module is taken as the reference module for simulation and the datasheet details are given in Table 2

2.5. Module Reverse Saturation Current. Module reverse saturation current, $I_{\mathrm{rs}}$, is given by (2) as follows.

$$
I_{\mathrm{rs}}=\frac{I_{\mathrm{SCr}}}{\left[\exp \left(q V_{\mathrm{OC}} / N_{S} k A T\right)-1\right]},
$$

where $q$ is the electron charge $\left(1.6 \times 10^{-19} \mathrm{C}\right), V_{\mathrm{oc}}$ is the Solkar module open-circuit voltage $(21.24 \mathrm{~V}), N_{s}$ is the 


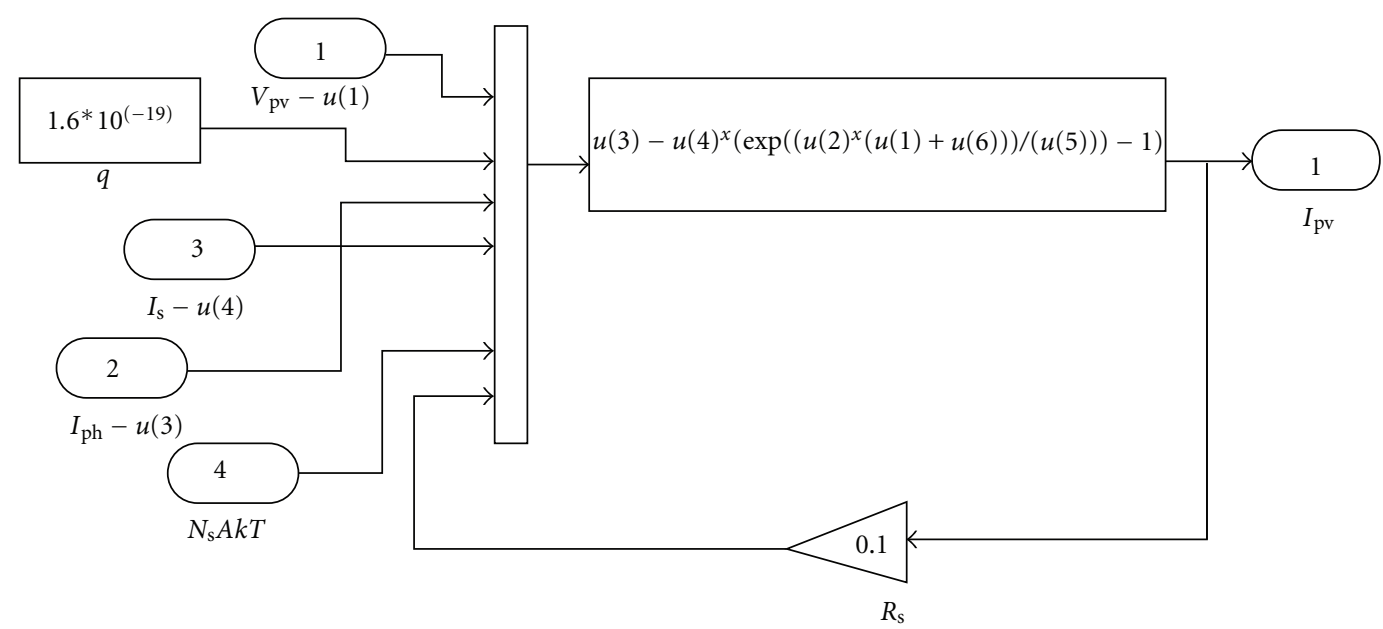

Figure 5: Module output current $I_{\mathrm{pv}}$.

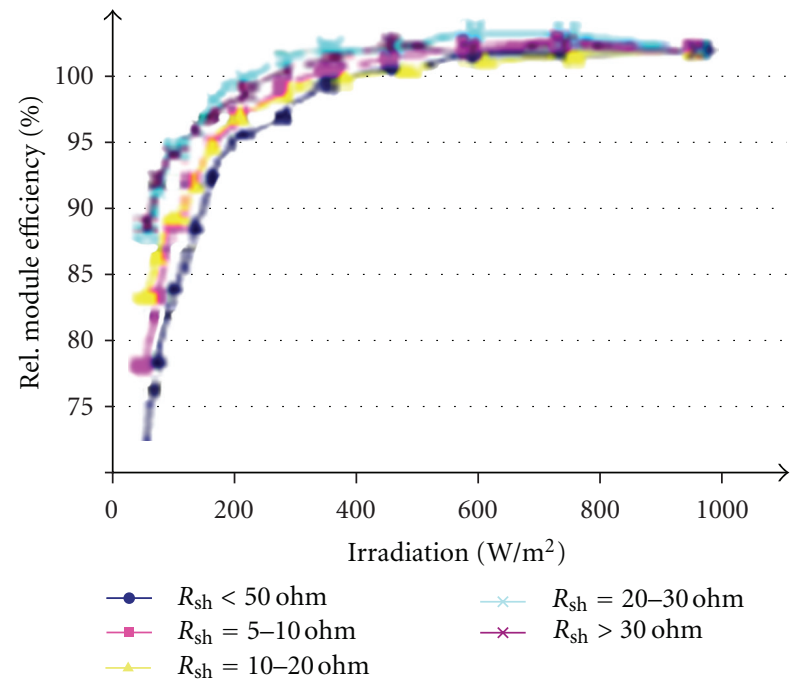

FIGURE 6: Relative efficiency versus irradiation.

TABLE 2: Electrical characteristic data of solkar $36 \mathrm{~W}$ PV module.

\begin{tabular}{lc}
\hline Description & Rating \\
\hline Rated power & $37.08 \mathrm{Wp}$ \\
Voltage at maximum power $\left(V_{\mathrm{mp}}\right)$ & $16.56 \mathrm{~V}$ \\
Current at maximum power $\left(I_{\mathrm{mp}}\right)$ & $2.25 \mathrm{~A}$ \\
Open circuit voltage $\left(V_{\mathrm{OC}}\right)$ & $21.24 \mathrm{~V}$ \\
Short circuit current $\left(I_{\mathrm{SCr}}\right)$ & $2.55 \mathrm{~A}$ \\
Total number of cells in series $\left(N_{\mathrm{s}}\right)$ & 36 \\
Total number of cells in parallel $\left(N_{p}\right)$ & 1 \\
\hline
\end{tabular}

Note. The electrical specifications are under standard test conditions (STCs) which means an irradiation of $1000 \mathrm{~W} / \mathrm{m}^{2}$ with an $\mathrm{AM} 1.5$ spectrum at $25^{\circ} \mathrm{C}$.

number of cells connected in series (36), $k$ is the Boltzmann constant $\left(1.3805 \times 10^{-23} \mathrm{~J} / \mathrm{K}\right)$, and $A$ is the ideality factor (1.6).
TABLE 3: $I_{\text {rs }}$ for various temperatures.

\begin{tabular}{lcc}
\hline S. no. & Temperature ${ }^{\circ} \mathrm{C}$ & Module reverse saturation current $(\mathrm{A})$ \\
\hline 1 & 25 & $1.182 * 10^{(-006)}$ \\
2 & 30 & $1.503 * 10^{(-006)}$ \\
3 & 40 & $2.377 * 10^{(-006)}$ \\
4 & 50 & $3.654 * 10^{(-006)}$ \\
5 & 90 & $1.609 * 10^{(-005)}$ \\
\hline
\end{tabular}

TABLE 4: $I_{0}$ for various temperatures.

\begin{tabular}{lcc}
\hline S. no. & Temperature ${ }^{\circ} \mathrm{C}$ & Module saturation current $(\mathrm{A})$ \\
\hline 1 & 25 & $1.182 * 10^{(-006)}$ \\
2 & 30 & $2.456 * 10^{(-006)}$ \\
3 & 40 & $9.92 * 10^{(-006)}$ \\
4 & 50 & $3.686 * 10^{(-005)}$ \\
5 & 90 & 0.003491 \\
\hline
\end{tabular}

Detailed Simulink model of (2) is shown in Figure 3.

Module reverse saturation current varies with temperature as shown in Table 3.

2.6. Module Saturation Current $I_{0}$. The module saturation current $I_{0}$ varies with the cell temperature and is given by

$$
I_{0}=I_{\mathrm{rs}}\left[\frac{T}{T_{r}}\right]^{3} \exp \left[\frac{q * E_{g 0}}{A k}\left\{\frac{1}{T_{r}}-\frac{1}{T}\right\}\right] \text {, }
$$

where $E_{g 0}$ is the bandgap energy of the semiconductor $\left(E_{g 0} \approx\right.$ $1.1 \mathrm{eV}$ for the polycrystalline $\mathrm{Si}$ at $25^{\circ} \mathrm{C}$ ).

This equation is simulated and shown in Figure 4 . The module operating temperature, reference temperature, and module reverse saturation current are taken as inputs.

The module saturation current $I_{0}$ is calculated for various temperatures and is given in Table 4 . 


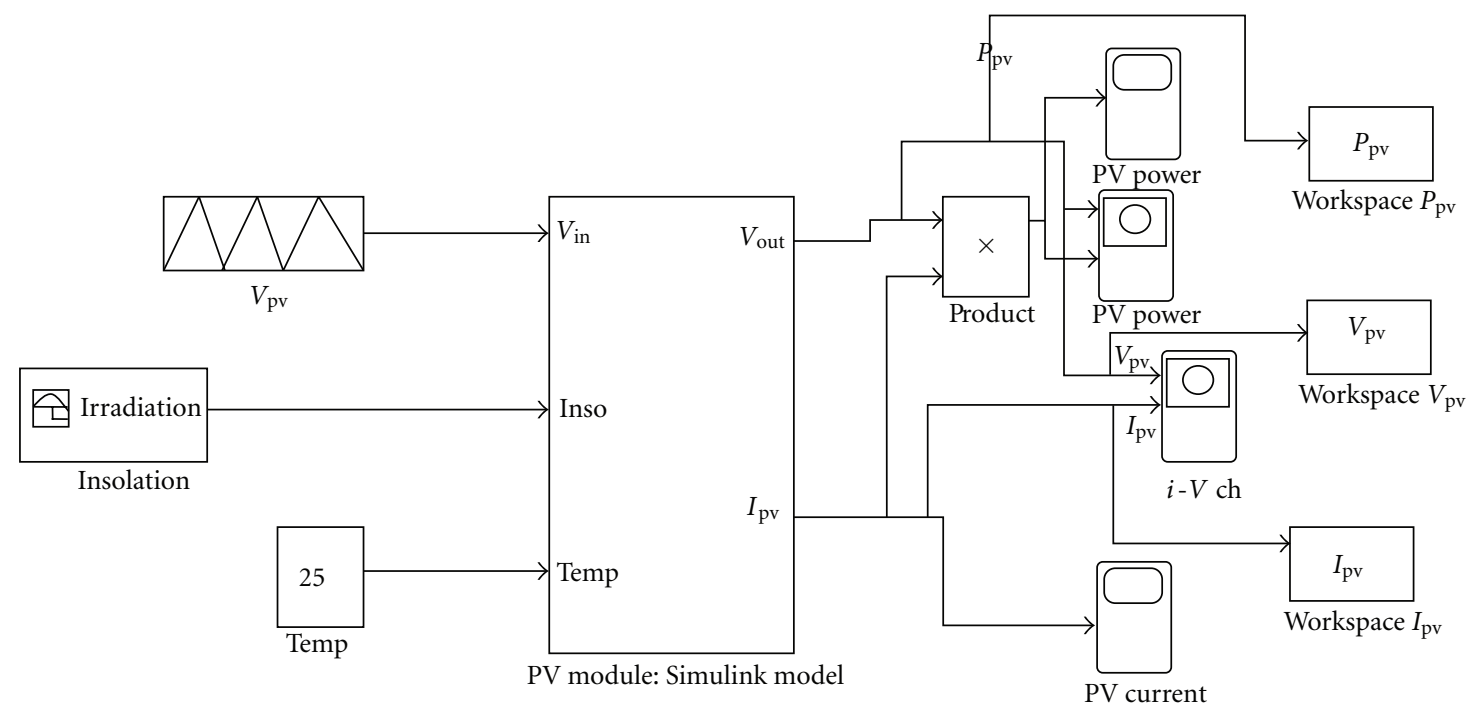

FIGURE 7: Simulation of $I_{\mathrm{pv}}$ Simulink model.

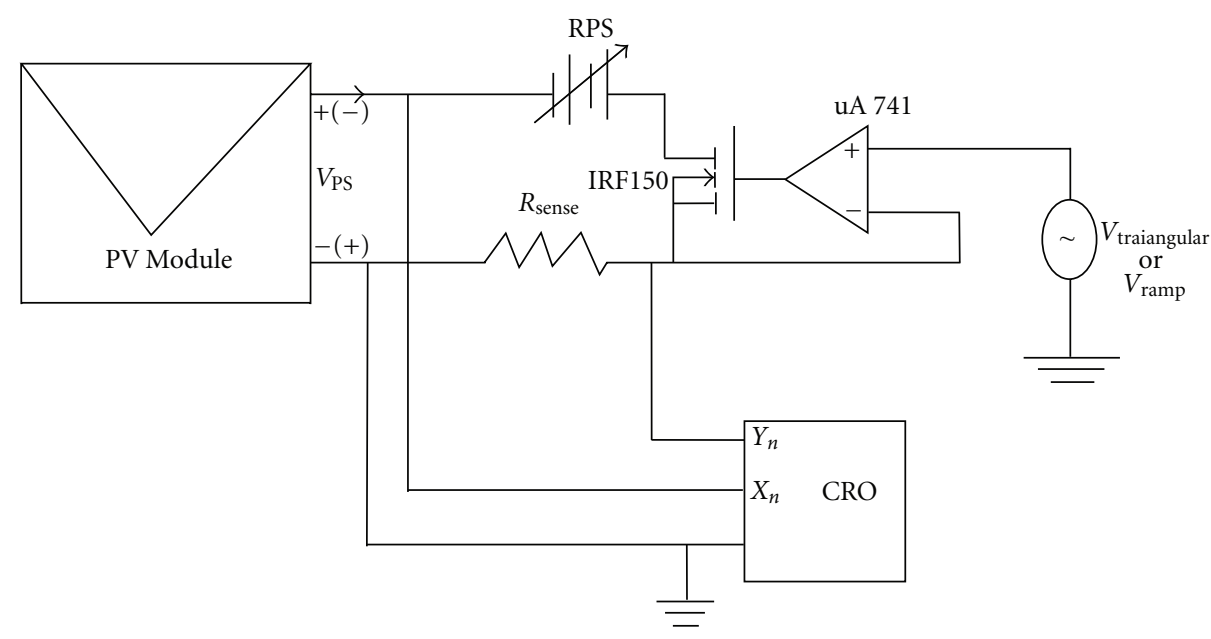

FIGURE 8: Circuit for obtaining the experimental characteristics of PV module.
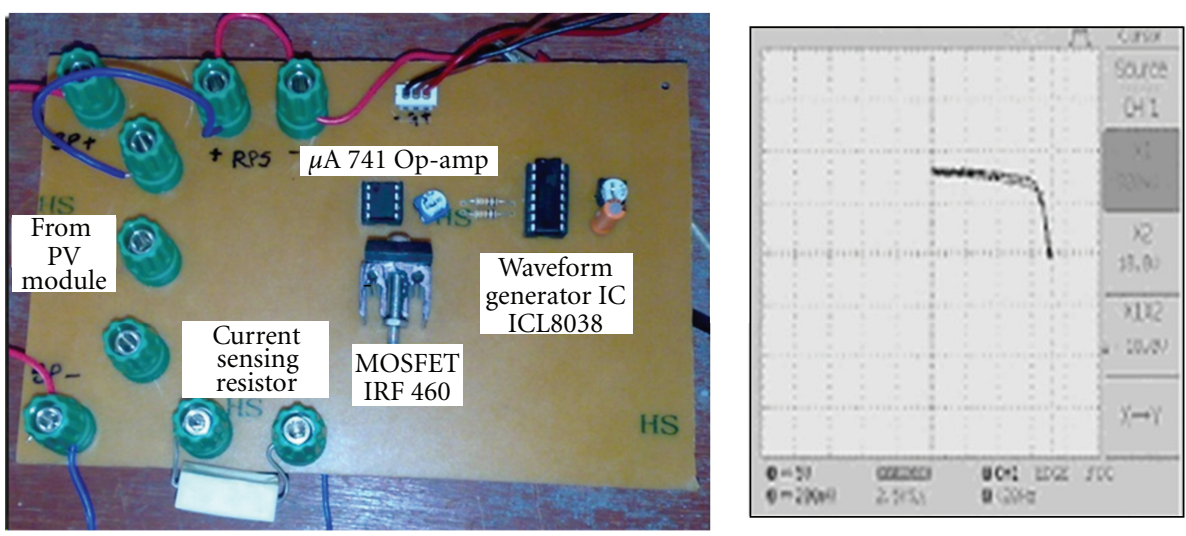

FIGURE 9: Hardware setup of an electronic load with sample snapshot of DSO screen for $V-I$ plot. 


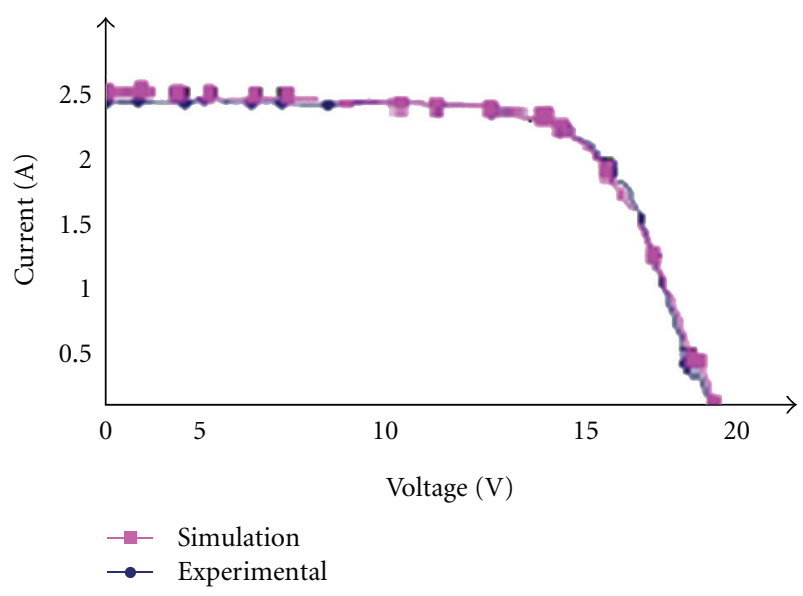

Figure 10: Simulation and experimental V-I characteristics.

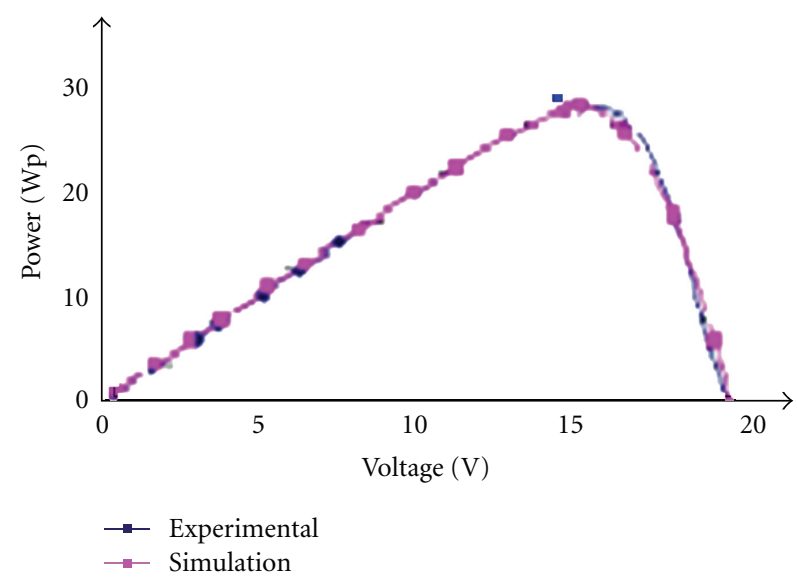

FIGURE 11: Simulation and experimental $P-V$ characteristics.

2.7. Module Output Current $I_{\mathrm{PV}}$. The basic equation that describes the current output of PV module $I_{\mathrm{PV}}$ of the singlediode model presented in Figure 1 is given by

$$
\begin{aligned}
I_{\mathrm{PV}}= & N_{P} * I_{\mathrm{ph}}-N_{P} * I_{0}\left[\exp \left\{\frac{q *\left(V_{\mathrm{PV}}+I_{\mathrm{PV}} R_{s}\right)}{N_{S} A k T}\right\}-1\right] \\
& -V_{\mathrm{PV}}+\left(I_{\mathrm{PV}} R_{S}\right) / R_{\mathrm{Sh}},
\end{aligned}
$$

where $N_{p}$ and $N_{S}$ are, respectively, the number of parallel and series connections of cells in the given photovoltaic module $\left(N_{p}=1\right.$ and $\left.N_{\mathrm{s}}=36\right), V_{\mathrm{PV}}=V_{\mathrm{oc}}=21.24 \mathrm{~V}, R_{s}$ is the equivalent series resistance of the module, and $R_{\mathrm{sh}}$ is the equivalent parallel resistance.

The current leakages, the tunnel effect, breakdown by micro plasmas, leaks along surface channels, and so forth, are modeled as a parallel resistance. The parallel resistance has its greatest effect when the voltage is lowest, that is, when the current passing through the diode of the equivalent circuit is very small. The effect of parallel resistance, when it is sufficiently small, is to reduce the open-circuit voltage and the fill factor [16]. The short-circuit current is not affected by it.
The graph between the relative efficiency of PV modules and isolation for various values $R_{\mathrm{sh}}$ is shown in Figure 6 [17]. In the graph, it can be seen that for large values $R_{\mathrm{sh}}$, the module efficiency at low values of isolation decreases by 3 to 5 percent.

When $R_{\text {sh }}$ is very large, we can neglect the same. In such case simulation values would be higher than the actual values by 3 to 5 percent at low values of isolation only. However there would not be any appreciable variation at normal/higher values of isolation.

The use of simplified circuit model in this paper makes this model suitable for power electronics designers who are looking for an easy and effective model for simulation of photovoltaic devices with power converters. The value of parallel resistance $R_{\mathrm{sh}}$ is generally high and hence neglected to simplify the model as given in (5).

The series resistance $R_{s}(0.1 \Omega)$ is the sum of several structural resistances of the PV module and its influence is stronger especially near the maximum power point region.

Equation (4) for the current output of PV module can be modified as

$$
I_{\mathrm{PV}}=N_{P} * I_{\mathrm{ph}}-N_{P} * I_{0}\left[\exp \left\{\frac{q *\left(V_{\mathrm{PV}}+I_{\mathrm{PV}} R_{s}\right)}{N_{S} A k T}\right\}-1\right] .
$$

The solution for (5) involves iteration and requires solving of algebraic loop in Simulink. To avoid this problem, the functional models are used in PV research for modeling of PV module.

2.8. Algebraic Loop Problem. Solving algebraic loop is an iterative process. A successful solution results only if the algebraic loop solver converges to a definite answer. Proper care is to be taken of the feedback loop to get quicker convergence. In this paper simplification of equation is done by excluding $R_{\mathrm{sh}}$.

The iterative MATLAB/Simulink model of output current $I_{\mathrm{pv}}$ is shown in Figure 5.

2.9. Simulink Model of $I_{\mathrm{PV}}$. All the above four blocks are interconnected to get Simulink model of $I_{\mathrm{PV}}$ for the PV module. This model takes insolation, temperature, and $V_{\mathrm{PV}}$ as inputs and calculates $I_{\mathrm{PV}} . V_{\mathrm{PV}}$ is varied from 0 to $21.5 \mathrm{~V}$. Simulink model of $I_{\mathrm{PV}}$ is simulated with the setup shown in Figure 7.

Detailed discussion of simulation steps of $I_{\mathrm{pv}}$ model for obtaining $I-V$ and $P-V$ characteristics under varying irradiation with constant temperature and constant irradiation with varying temperature is available in [18].

2.10. Experimental Validation. The hardware for validating the results obtained in developed Simulink model is given in Figure 9.

The description of experimental circuit given in Figure 8 is as follows.

(i) The Op-Amp, the MOSFET, and the resistor $R_{\text {sense }}$ are connected so that the current of the solar 


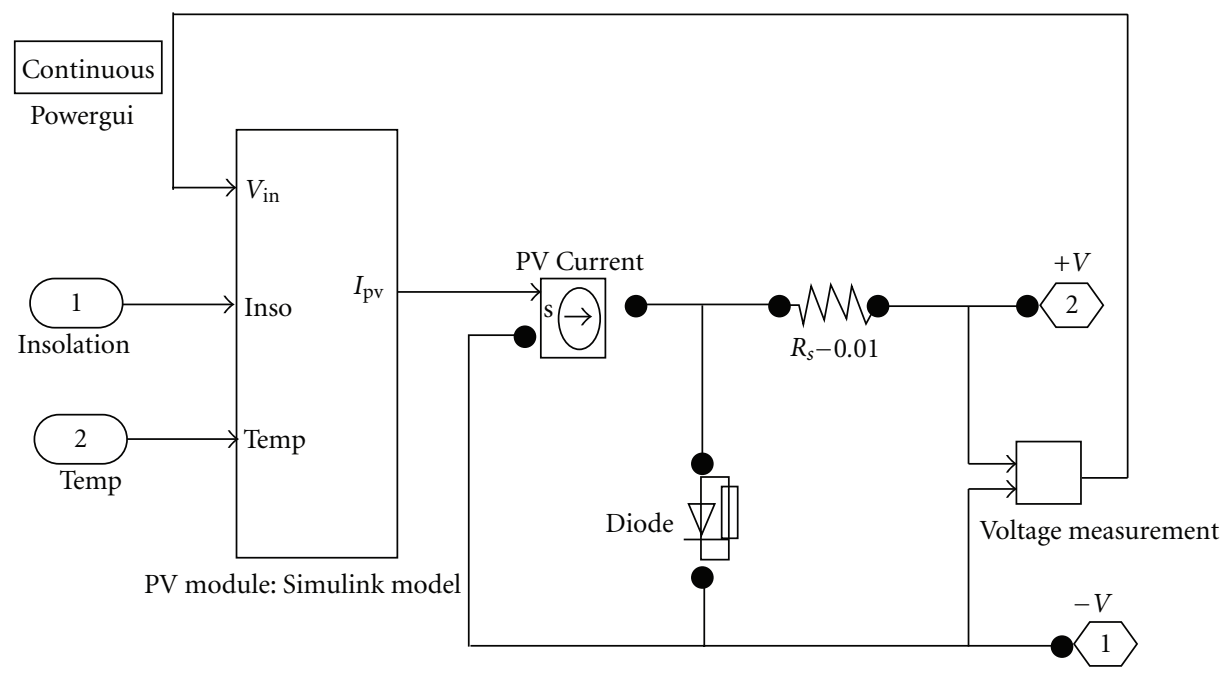

FIGURE 12: Detailed circuit model of PV module.

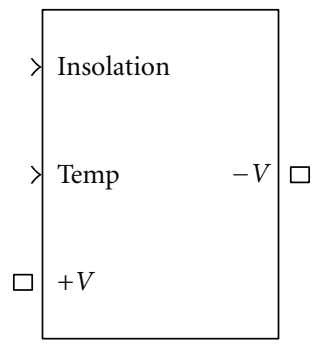

Figure 13: Circuit model block of PV module.

panel is proportional to the voltage applied to the noninverting port of the Op-Amp.

(ii) A linear MOSFET (IRF 150/IRF 460) is used. GateSource port of the MOSFET is driven by a lowfrequency triangular wave signal.

(iii) DSO has been used and therefore repetitive trigger signal is not required and only a slow changing ramp signal is required to change the current from zero to the short-circuit value.

(iv) The experimental characteristics smoothened by curve fitting along with characteristics of Simulink model are shown in Figures 10 and 11.

It can be seen from Figure 10 that the simulated value of current at $\lambda=1000 \mathrm{~W} / \mathrm{m}^{2}$ and $T=25^{\circ} \mathrm{C}$ is $2.55 \mathrm{~A}$ while the experimental value of current is $2.49 \mathrm{~A}$, giving a percentage error of 2.35 .

The simulated values of current using the developed model are higher than the experimental values of current by about $2 \%$ at higher values of insolation and hence the circuit model has reasonable accuracy.

The above graph also shows that useful voltage output varies from $12 \mathrm{~V}$ to $19 \mathrm{~V}$. The maximum power point for all these temperatures lies between these voltages.

\section{Circut-Oriented Model of PV Module}

In the equivalent circuit of a PV cell, as shown in Figure 1, the voltage available across the PV cell is nothing but the $\mathrm{PN}$ junction forward bias voltage of $0.6 \mathrm{~V}$. The open-circuit voltage of the PV module is $21.24 \mathrm{~V} / 36$ cells $=0.594 \mathrm{~V} \approx$ $0.6 \mathrm{~V}$.

Simulink model of $I_{\mathrm{PV}}$, developed in Section 2, provides the module current $I_{\mathrm{PV}}$. This PV current is calculated from irradiation and temperature and is the input to be used directly in the circuit model.

The voltage at the output terminal of the model is fed back as the voltage input $V_{\text {in }}$ for Simulink model of $I_{\mathrm{PV}}$ [10]. A small resistance of $0.01 \Omega$ is added to the circuit to aid the charging of capacitor normally used with the current source.

The detailed circuit model of PV module is shown in Figure 12. The circuit model block of PV module is given in Figure 13.

Further, the forward bias voltage of the diode shown in Figure 12 is taken as $19 \mathrm{~V}$ (as it represents the series connection of $36 \mathrm{PV}$ cells) which is the higher value of useful voltage level.

Here, a voltage value is chosen initially and the iteration of power equation is carried out as done in normal functional PV model as it involves the algebraic loop problem.

\section{Design of PV Maximum Power Extraction System}

With the variation of irradiation and temperature, the power output of PV module varies continuously. The maximum power point tracking (MPPT) algorithm is used for extracting the maximum power from the solar PV module and transferring that power to the load [15]. A DC-DC converter (step up/step down), as shown in Figure 14, serves the purpose of transferring maximum power from the PV module to the load and acts as an interface between the load and the module. 


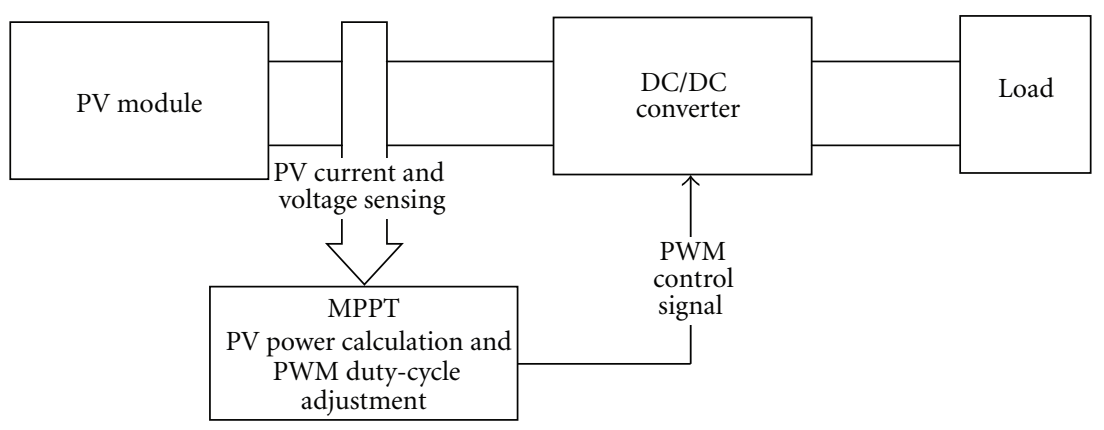

FIGURE 14: DC-DC converter for operation at the MPP.

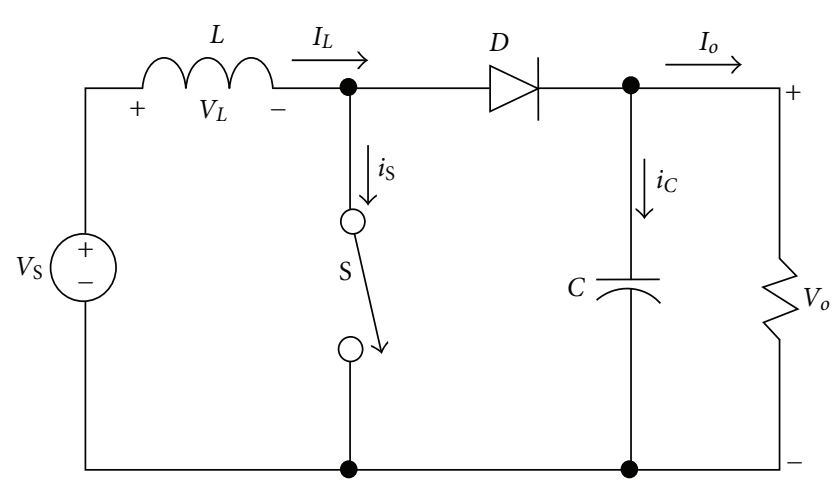

Figure 15: Configuration of DC to DC boost converter.

By changing the duty cycle of the PWM control signal, the load impedance as seen by the source varies and matches the point of the peak power of the source so as to transfer the maximum power.

4.1. Power Electronic Circuit. The PV modules are always used with DC-to-DC converters to obtain the maximum power point operation. The types of converters used are buck, boost, and buck-boost. For battery charging applications buck-boost configuration is preferred where as boost converters are used for grid-connected applications. DC-DC boost converters are used often in PV systems to step up the low module voltage to higher load voltages. Hence, DC-DC boost converter is used for the design of MPPT controller.

4.2. Design of DC-DC Boost Converter. The boost converter configuration, as shown in Figure 15, consists of a DC input voltage source $V_{s}$, boost inductor $L$, controlled switch $S$, diode $D$, filter capacitor $C$, and load resistance $R$.

If the switch operates with a duty ratio $D$, the $\mathrm{DC}$ voltage gain of the boost converter is given by

$$
M_{v}=\frac{V_{o}}{V_{s}}=\frac{1}{1-D},
$$

where $V_{s}$ is input voltage, $V_{o}$ is output voltage, and $D$ is the duty cycle of the pulse width modulation (PWM) signal used to control the MOSFET ON and OFF states.
TABLE 5: Component values of DC-to-DC boost converter.

\begin{tabular}{lc}
\hline Description & Rating \\
\hline Inductor & $120 \mu \mathrm{H}$ \\
MOSFET & IRF P460 \\
Power diode & $1 \mathrm{~N} 5408$ \\
Capacitor & $330 \mu \mathrm{F}$ \\
Resistive load & $50 \Omega, 50 \mathrm{~W}$ \\
Switching frequency & $20 \mathrm{kHz}$ \\
\hline
\end{tabular}

The boost converter operates in the continuous conduction mode for value of inductance $L>L_{b}$ where,

$$
L_{b}=\frac{\left(1-D^{2}\right) D R}{2 f},
$$

where $L_{b}$ is the minimum value of inductance for continuous conduction.

The current supplied to the output RC circuit is discontinuous. Thus, a larger filter capacitor is required to limit the output voltage ripple. The minimum value of filter capacitor that provides the output DC current to the load when the diode $D$ is off is given by $C_{\min }$. The minimum value of the filter capacitance, that results in the ripple voltage $V_{c}$, is given by

$$
C_{\min }=\frac{D V_{o}}{V_{r} R F} .
$$

Designed component values of DC-to-DC boost converter used for simulation are given in Table 5.

4.3. Design of MPPT. The DC-DC converter (with configuration given in Figure 15 and component values in Table 5) is simulated with battery supply as shown in Figure 16.

With DC supply, the converter voltage boost ratio is directly proportional to the duty cycle.

The battery supply in circuit shown in Figure 16 is replaced by the developed circuit model in Section 3 and simulated as shown in Figure 17.

The detailed experimental verification with circuit response of this developed circuit model is available in [19].

For the design of MPPT, the data is collected through simulation with the developed circuit model and results are tabulated in Table 6. 


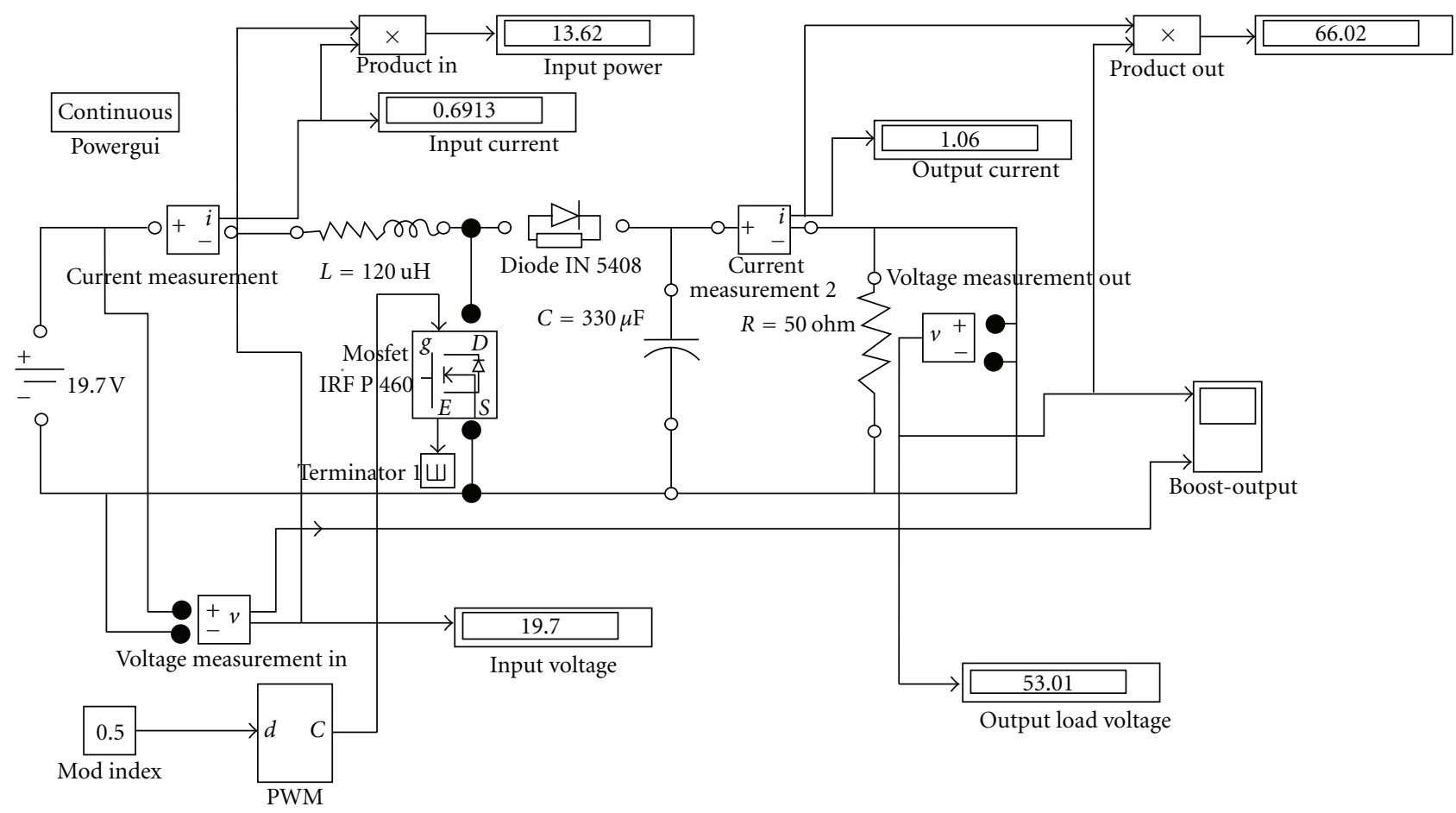

Figure 16: Boost converter circuit with DC supply.

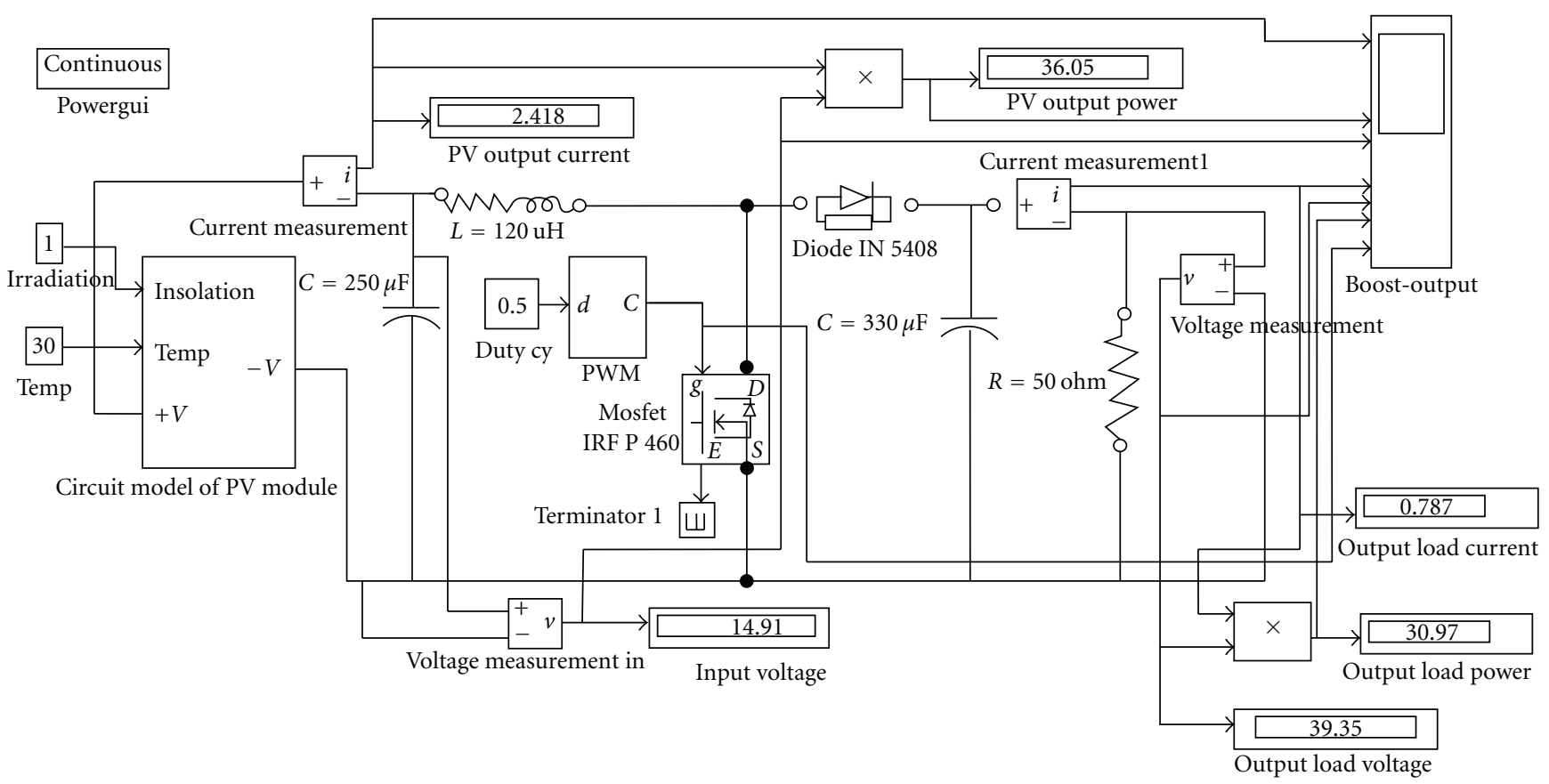

FIgURE 17: Boost converter circuit with PV input.

From Table 6, it can be seen that for lower values of irradiation and constant load, the duty cycle has to be reduced from 0.41 for irradiation of $1000 \mathrm{~W} / \mathrm{m}^{2}$ to 0.2 for irradiation of $500 \mathrm{~W} / \mathrm{m}^{2}$. This variation coincides with the graph shown in Figure 18, as found in [20], where the duty cycle variation with respect to irradiation is reported.
4.4. MPPT Control Algorithm. Many MPPT techniques have been proposed in the literature; examples are the Perturb and Observe (P\&O), Incremental Conductance (IC), Fuzzy Logic, and so forth. The $\mathrm{P} \& \mathrm{O}$ algorithm is very popular and simple. So it is used in this paper. The power graph for $\mathrm{P} \& \mathrm{O}$ algorithm is shown in Figure 19. 
TABLE 6: Duty cycle variation.

\begin{tabular}{|c|c|c|c|c|c|c|}
\hline Duty cycle & Input voltage $(V)$ & Input current $(A)$ & $\begin{array}{l}\text { Input power } \\
\left(W_{P}\right)\end{array}$ & $\begin{array}{l}\text { Output voltage } \\
(V)\end{array}$ & $\begin{array}{l}\text { Output current } \\
(A)\end{array}$ & $\begin{array}{l}\text { Output power } \\
(W)\end{array}$ \\
\hline \multicolumn{7}{|c|}{ Irradiation $-1000 \mathrm{~W} / \mathrm{m}^{2} \mathrm{Temp}-25^{\circ} \mathrm{C}$} \\
\hline 0.4 & 17.82 & 2.059 & 36.69 & 40.08 & 0.8106 & 32.13 \\
\hline 0.41 & 16.7 & 2.303 & 38.46 & 40.45 & 0.8089 & 32.72 \\
\hline 0.5 & 15.05 & 2.44 & 36.72 & 39.06 & 0.7812 & 30.52 \\
\hline \multicolumn{7}{|c|}{ Irradiation $-700 \mathrm{~W} / \mathrm{m}^{2} \mathrm{Temp}-25^{\circ} \mathrm{C}$} \\
\hline 0.3 & 17.6 & 1.375 & 24.21 & 32.46 & 0.6492 & 21.08 \\
\hline \multicolumn{7}{|c|}{ Irradiation- $-500 \mathrm{~W} / \mathrm{m}^{2} \mathrm{Temp}-25^{\circ} \mathrm{C}$} \\
\hline 0.2 & 17.64 & 0.8661 & 15.28 & 25.76 & 0.515 & 13.27 \\
\hline
\end{tabular}

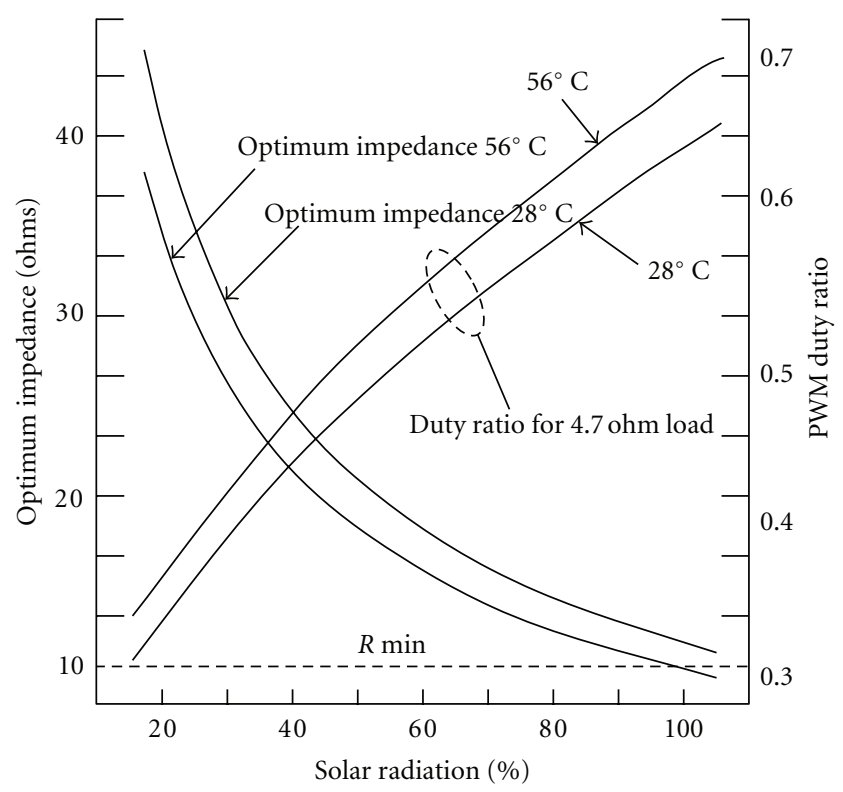

FIGURE 18: Duty cycle variation with respect to irradiation.

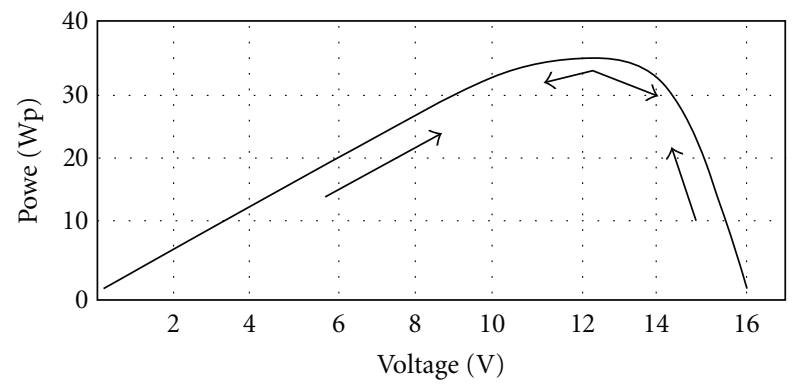

Figure 19: Power graph for $\mathrm{P}$ and $\mathrm{O}$ algorithm.

In $\mathrm{P} \& \mathrm{O}$ algorithm, a slight perturbation $(\Delta D=0.01)$ is introduced in the system. This perturbation causes the power of the solar module to change. If the power increases due to the perturbation, then the perturbation is continued $(D+\Delta D)$ in that direction. After the peak power is reached, the power at the next instant decreases and after that the perturbation reverses $(D-\Delta D)$. The flow chart of MPPT algorithm is shown in Figure 20.
The Simulink model for P \& O MPPT algorithm is shown in Figure 21. $V_{\text {in }}$ and $I_{\text {in }}$ are taken as input to the MPPT unit and duty cycle is obtained as the output.

The above MPPT unit is placed as closed-loop control in the simulation circuit, as shown in Figure 17 and the detailed Simulink model for closed-loop control of developed circuit model of PV module with MPPT control unit is shown in Figure 22.

\section{Hardware Implementation}

The schematic diagram of the proposed hardware system is shown in Figure 23.

(i) The DC-DC boost converter acts as an interface between the PV module and the load.

(ii) The voltage and current output are sensed and an error signal in digital is generated by the software.

(iii) The error signal in digital form is given to the DAC (0808) which converts it to the corresponding analog signal.

(iii) This signal is then compared with a high-frequency triangular wave of $20 \mathrm{kHz}$. The pulse generated given is to the gate of the power semiconductor device (MOSFET), thereby changing the duty cycle of the converter.

(iv) This generated pulse must be able to trigger the power circuit of the MOSFET.

(v) Thus the source impedance is matched with the load impedance and maximum power is transferred.

The hardware setup of the proposed system is shown in Figure 24. The microcontroller programming should be fed with the required range of duty cycle as given in Table 6 for quicker response.

The experiment is carried out for $1000 \mathrm{~W} / \mathrm{m}^{2}$ at $25^{\circ} \mathrm{C}$. The experimental values of PV module power and current are lower by about 2 to 5 percent compared to the simulation values, as shown in Figure 25.

Thus the performance of the developed circuit model, in closed-loop control, follows the simulation values with reasonable accuracy. 


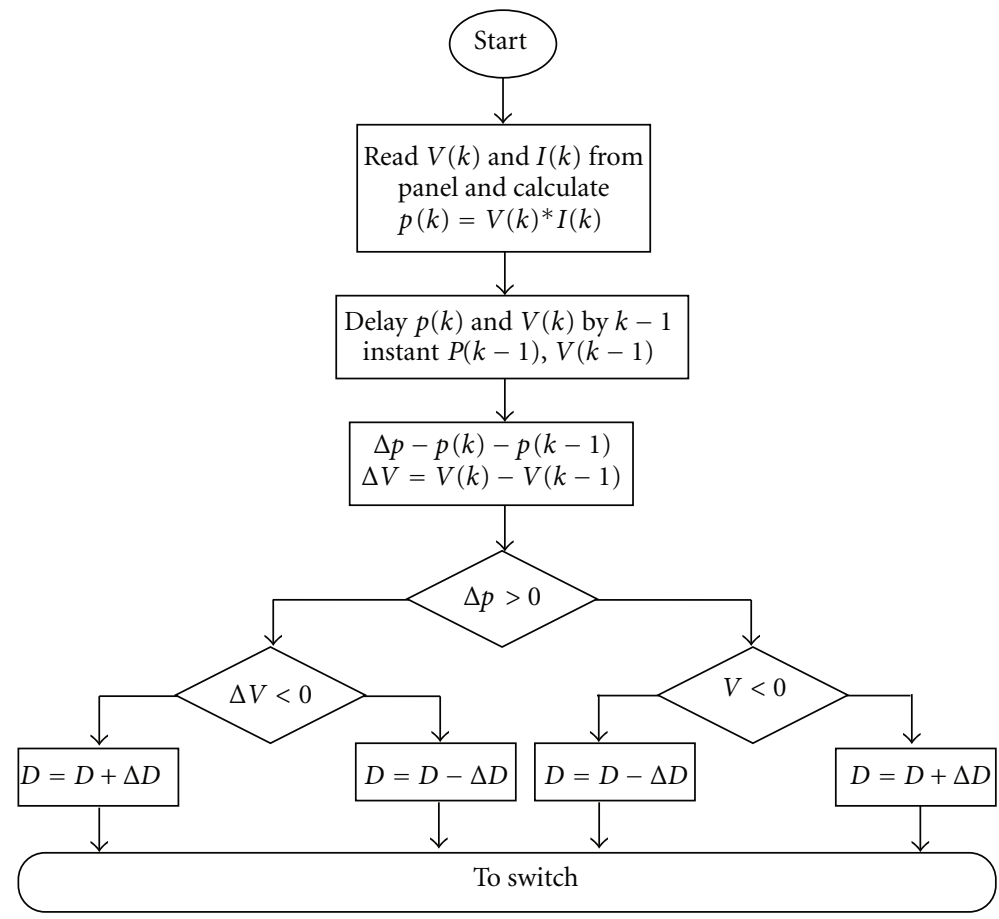

FIgUre 20: Flow chart of P\&O MPPT algorithm.

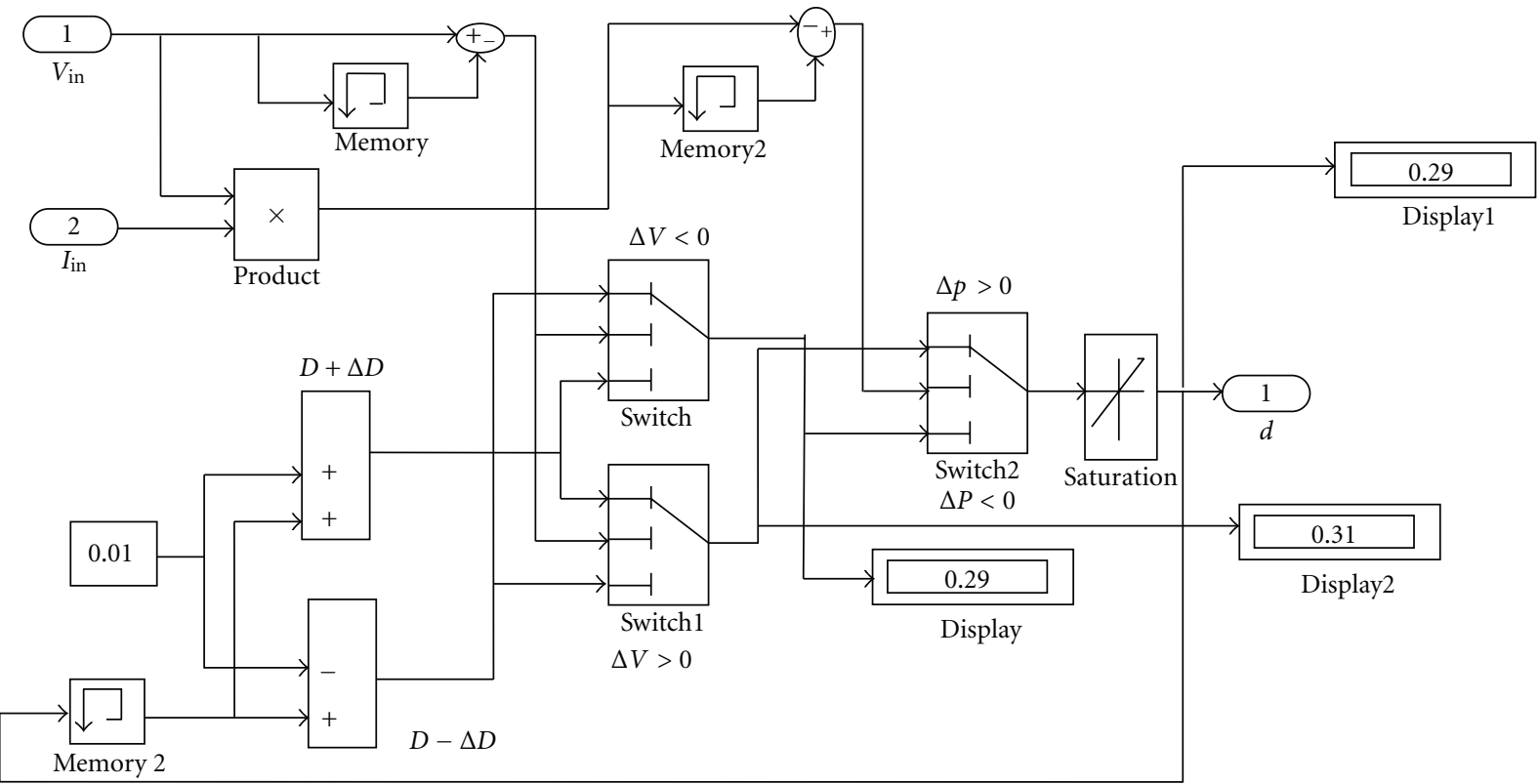

FIGURE 21: Simulink model for P\&O MPPT algorithm.

\section{Results and Discussion}

In Section 2, in (1) and Figure 1, it can be seen that the PV current $I_{\mathrm{ph}}$ is a function of the solar irradiation and is the only energy conversion process in which light energy is converted to electrical energy.

The next two equations, (2) and (3), indicate that the PV voltage is a function of the junction voltage of diode, which is the material property of the semiconductors, susceptible to failure at higher temperatures. The physical equations governing the $\mathrm{PV}$ module (also applicable to PV cell) is elaborately presented with numerical values of module saturation current at various temperatures. Hence, this circuit model presents the relationship between module parameters and circuit performance.

In Section 3, voltage level of the PV module is selected as $19 \mathrm{~V}$. However, for functional PV models used in other papers, the voltage level for the iterative process is chosen as 


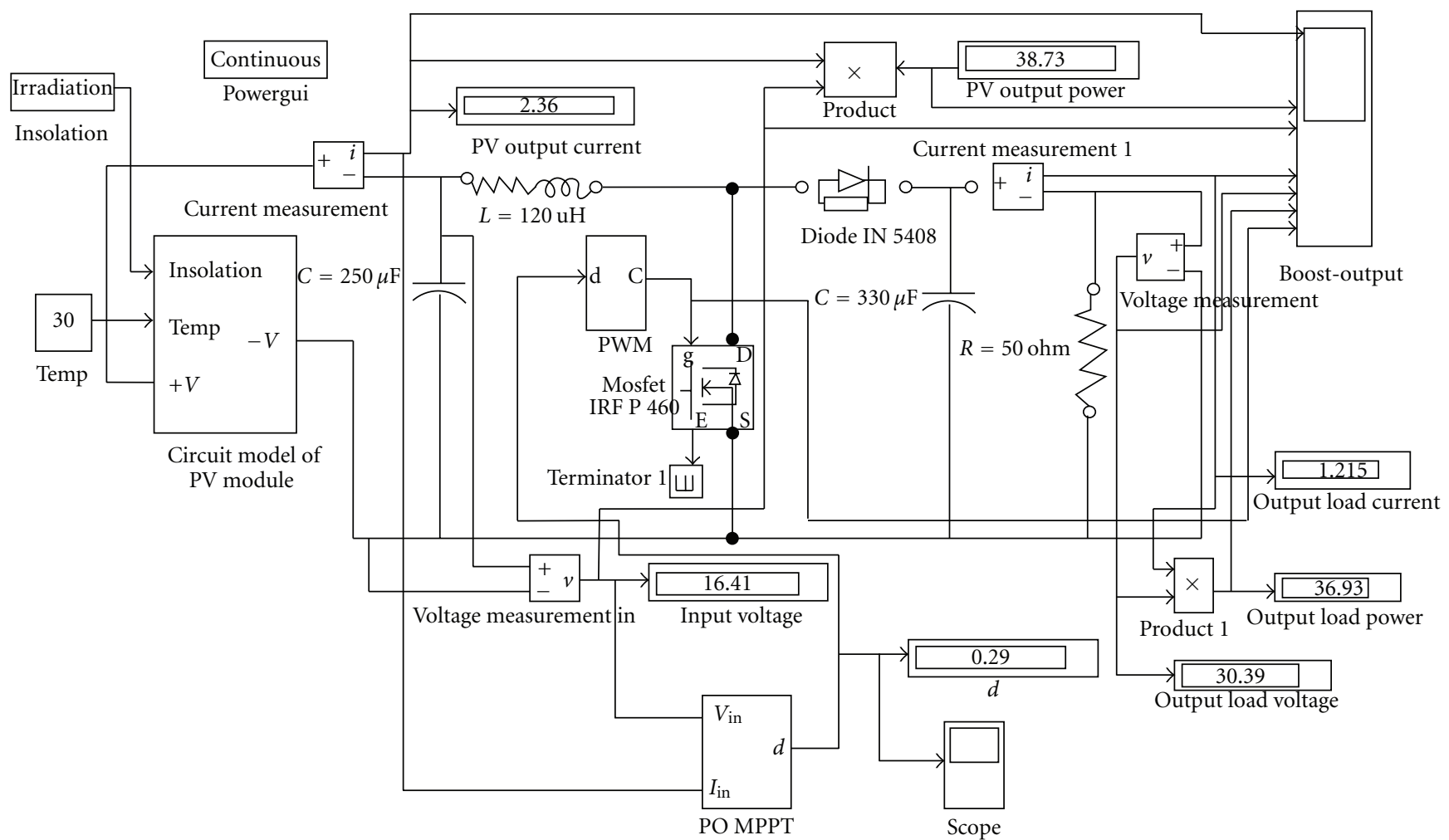

FIgURE 22: MPPT control circuit.

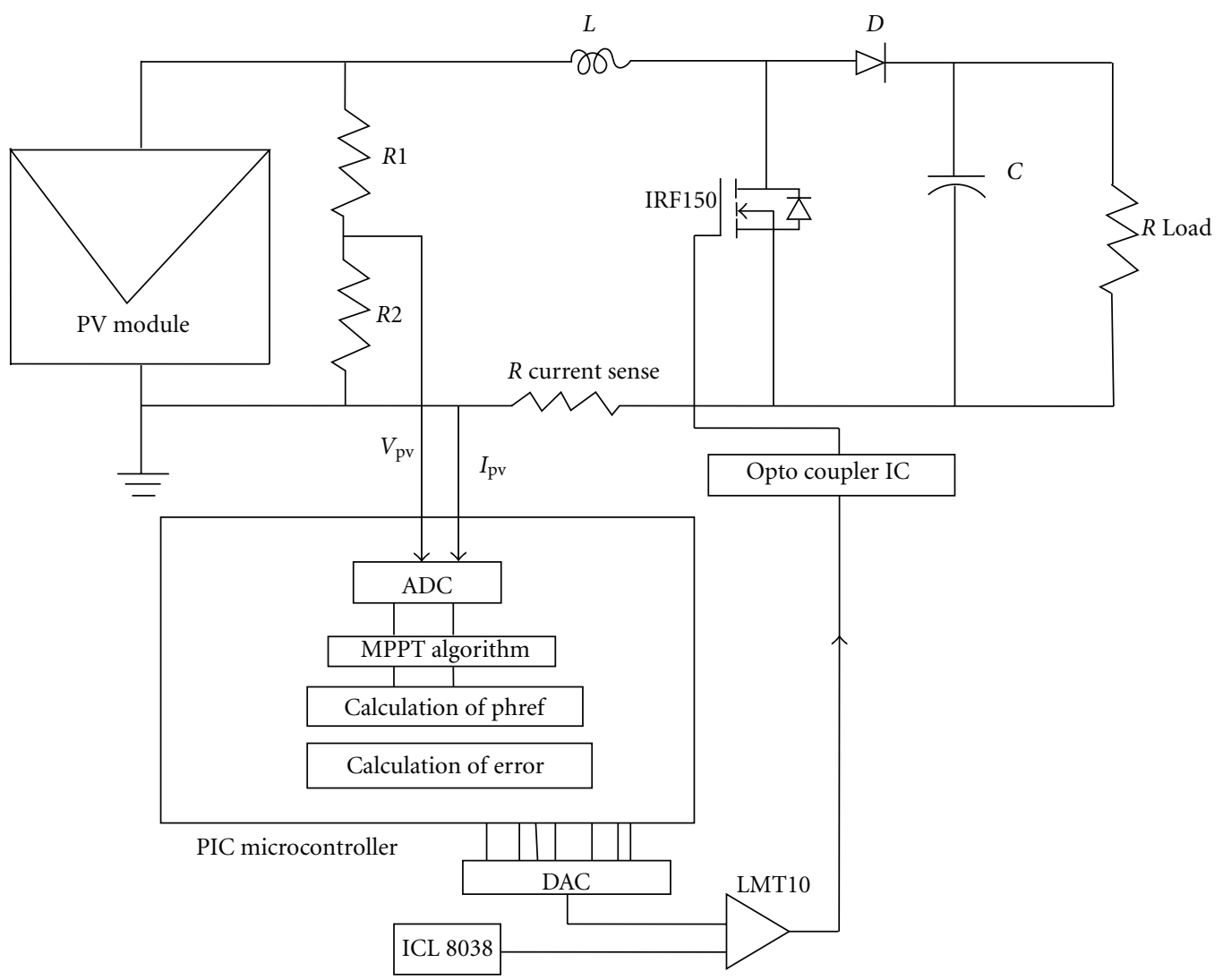

FIgURE 23: Proposed hardware system. 


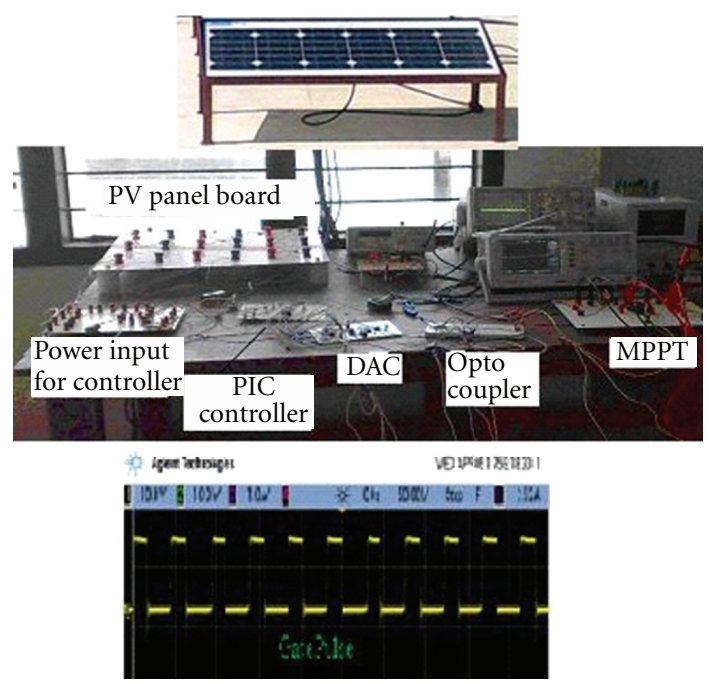

Figure 24: Hardware of MPPT.

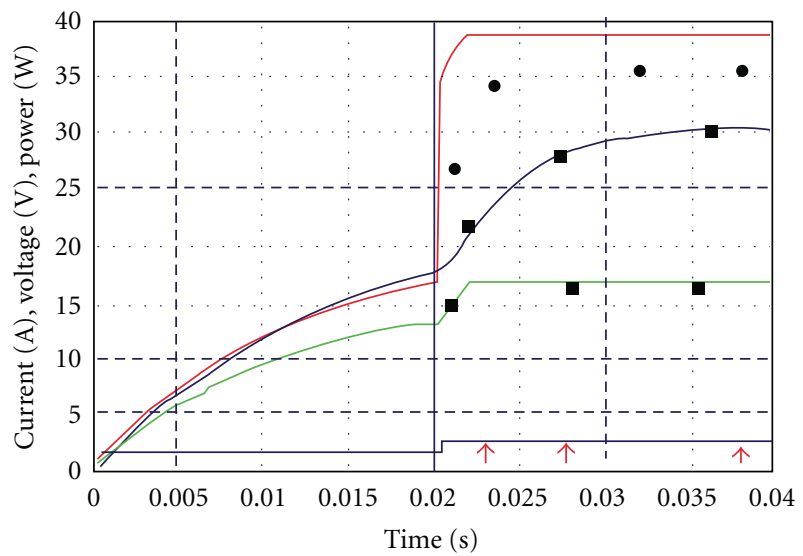
个 Ex. PV current
- Ex. PV power
- Ex. PV and con. voltage
— Input current

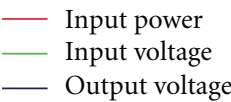

FIGURE 25: Variation of current, power for variable irradiation with experimental results.

per the convenience of end-circuit requirements and affect the circuit performance considerably. This has an effect on the temperature performance of the circuit. So the selection of this voltage level which is very important has to be selected appropriately.

\section{Conclusion}

Circuit model of photovoltaic (PV) module is presented in this paper, which can be used as a common platform by material scientists as well as power electronic circuit designers to develop the better PV power plant.

\section{Acknowledgment}

The authors wish to thank the management of SSN College of Engineering, Chennai for providing experimental and computational facilities to carry out this work at SSNCE EEE Department Solar Photovoltaic Research Laboratory.

\section{References}

[1] N. Pandiarajan and R. Muthu, "Viability analysis on photovoltaic configurations," in Proceedings of the IEEE Region 10 Conference (TENCON '08), Hyderabad, India, November 2008.

[2] "PV Balance of Systems Conference Berlin, Germany," June 2011, http://www.PV-insider.com/.

[3] J. A. Gow and C. D. Manning, "Development of a photovoltaic array model for use in power-electronics simulation studies," IEE Proceedings on Electric Power Applications, vol. 146, no. 2, pp. 193-200, 1999.

[4] M. E. Ropp and S. Gonzalez, "Development of a MATLAB/ simulink model of a single-phase grid-connected photovoltaic system," IEEE Transactions on Energy Conversion, vol. 24, no. 1, pp. 195-202, 2009.

[5] M. Veerachary, "PSIM circuit-oriented simulator model for the nonlinear photovoltaic sources," IEEE Transactions on Aerospace and Electronic Systems, vol. 42, no. 2, pp. 735-740, 2006.

[6] I. H. Altas and A. M. Sharaf, "A photovoltaic array simulation model for matlab-simulink GUI environment," in Proceedings of the International Conference on Clean Electrical Power (ICCEP '07), pp. 341-345, Capri, Italy, May 2007.

[7] R. C. Campbell, "A circuit-based photovoltaic array model for power system studies," in Proceedings of the 39th North American Power Symposium (NAPS '07), pp. 97-101, Las Cruces, NM, USA, October 2007.

[8] S. Chowdhury, S. P. Chowdhury, G. A. Taylor, and Y. H. Song, "Mathematical modelling and performance evaluation of a stand-alone polycrystalline PV plant with MPPT facility," in Proceedings of the IEEE Power and Energy Society, General Meeting: Conversion and Delivery of Electrical Energy in the 21st Century (PES '08), Pittsburgh, Pa, USA, July 2008.

[9] M. G. Villalva, J. R. Gazoli, and E. Ruppert Filho, "Modeling and circuit-based simulation of photovoltaic arrays," in Proceedings of the Brazilian Power Electronics Conference (COBEP '09), pp. 1244-1254, Bonito-Mato Grosso do Sul, Brazil, October 2009.

[10] M. G. Villalva, J. R. Gazoli, and E. R. Filho, "Comprehensive approach to modeling and simulation of photovoltaic arrays," IEEE Transactions on Power Electronics, vol. 24, no. 5, pp. 11981208, 2009.

[11] J. H. Jung and S. Ahmed, "Model construction of single crystalline photovoltaic panels for real-time simulation," in Proceedings of the 2nd IEEE Energy Conversion Congress and Exposition (ECCE '10), pp. 342-349, Atlanta, Ga, USA, September 2010.

[12] S. Nema, R. K. Nema, and G. Agnihotri, "Matlab/Simulink based study of photovoltaic cells/modules/array and their experimental verification," International Journal of Energy and Environment, vol. 1, no. 3, pp. 487-500, 2010.

[13] T. F. Elshatter, M. T. Elhagry, E. M. Abou-Elzahab, and A. A. T. Elkousy, "Fuzzy modeling of photovoltaic panel equivalent circuit," in Proceedings of the Conference Record of the 28th IEEE Photovoltaic Specialists Conference, pp. 1656-1659, 2000. 
[14] M. Balzani and A. Reatti, "Neural network based model of a PV array for the optimum performance of PV system," in IEEE Research in Microelectronics and Electronics, vol. 2, pp. 123126, July 2005.

[15] Aeronautics and Space Administration, (NASA-CR-149364) National, Solar Cell Array Design Handbook, vol. 1, Jet Propulsion Lab, 1976.

[16] K. Nishioka, N. Sakitani, Y. Uraoka, and T. Fuyuki, "Analysis of multicrystalline silicon solar cells by modified 3-diode equivalent circuit model taking leakage current through periphery into consideration," Solar Energy Materials and Solar Cells, vol. 91, no. 13, pp. 1222-1227, 2007.

[17] P. Grunow, S. Lust, and D. Sauter, "Weak light performance and annual yields of PV modules and systems as a result of the basic parameter set of industrial solar cells," in Proceedings of the 19th European Photovoltaic Solar Energy Conference, Paris, France, June 2004.

[18] N. Pandiarajan and R. Muthu, "Mathematical Modeling of Photovoltaic Module with Simulink," in Proceedings of the International Conference on Electrical Energy Systems (ICEES '11), Jan 2011.

[19] N Pandiarajan and R Muthu, "Development of Power Electronic Circuit Oriented Model of Photovoltaic Module," International Journal of Advanced Engineering Technology, vol. 2, no. 4th, pp. 118-127, 2011.

[20] K. H. Hussein, I. Muta, T. Hoshino, and M. Osakada, "Maximum photovoltaic power tracking: an algorithm for rapidly changing atmospheric conditions," IEE Proceedings-Generation, Transmission and Distribution, vol. 142, no. 1, pp. 5964, 1995. 


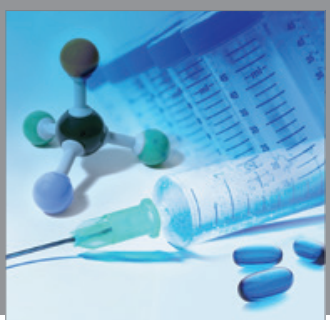

International Journal of

Medicinal Chemistry

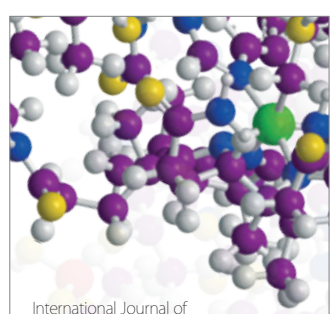

Carbohydrate Chemistry

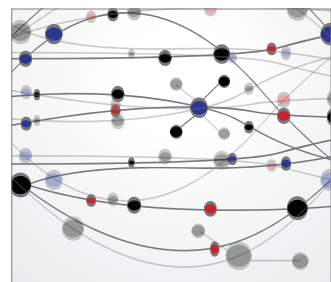

The Scientific World Journal
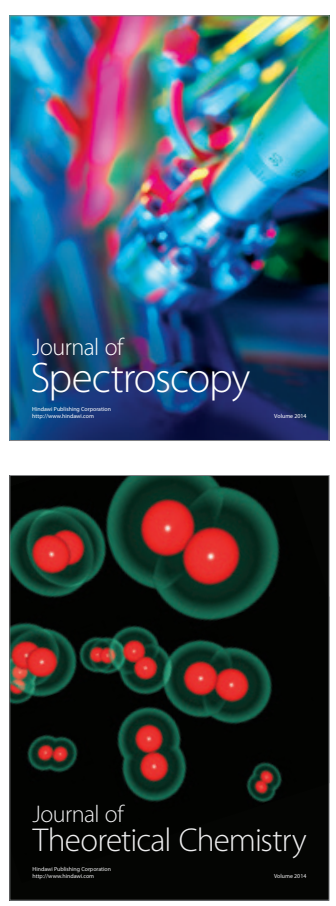
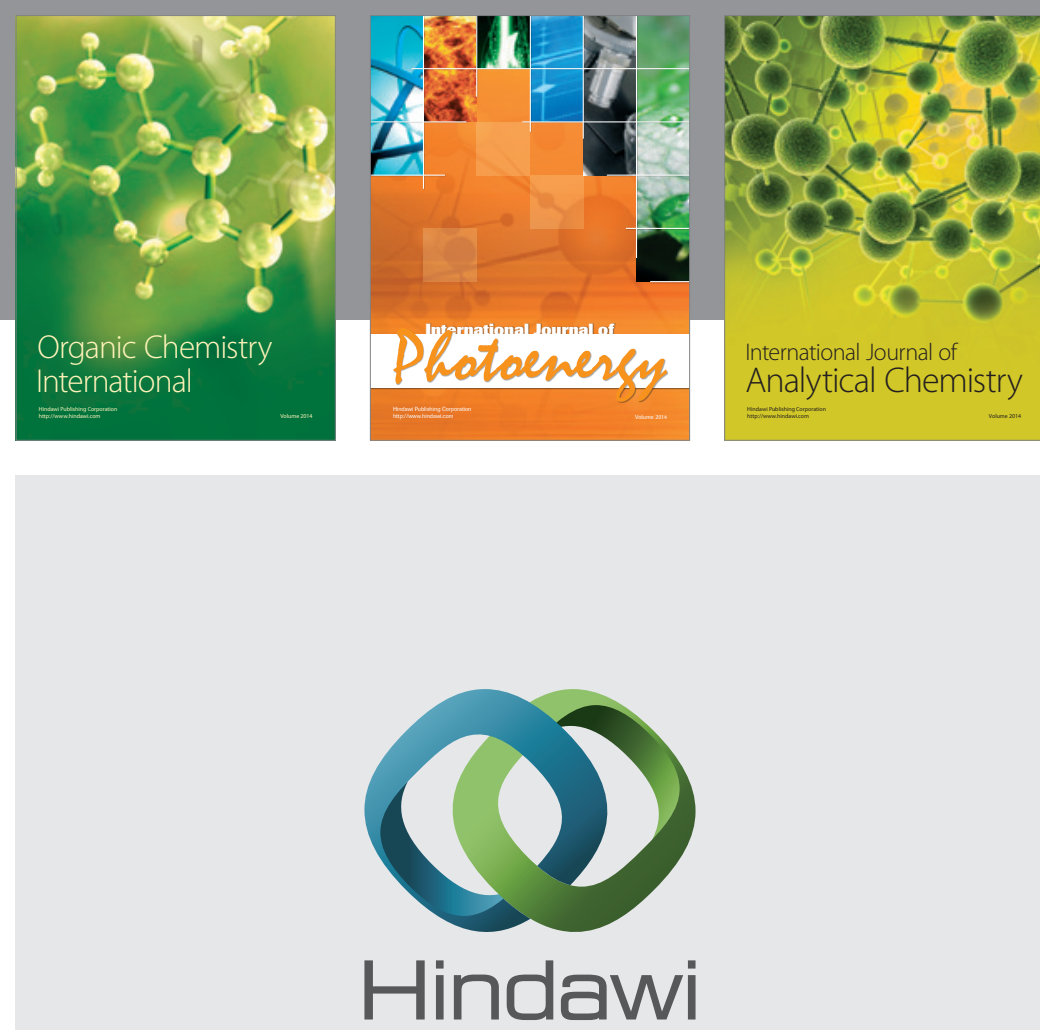

Submit your manuscripts at

http://www.hindawi.com
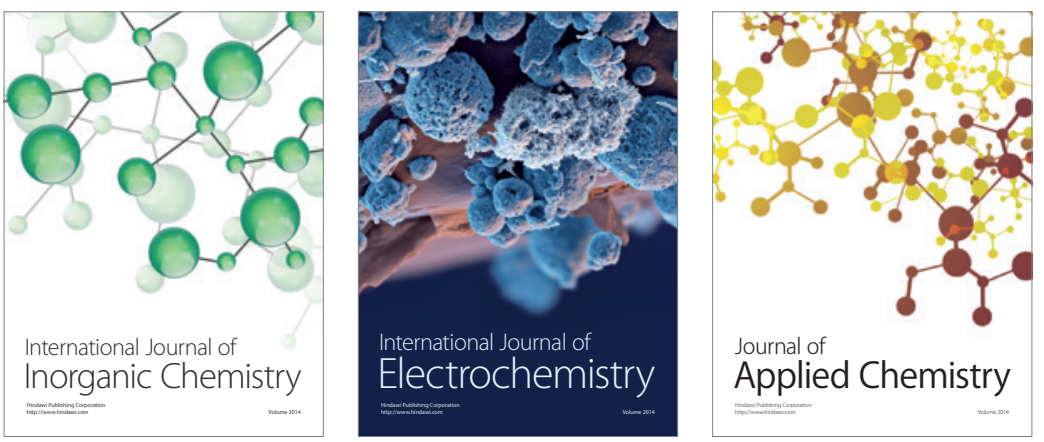

Journal of

Applied Chemistry
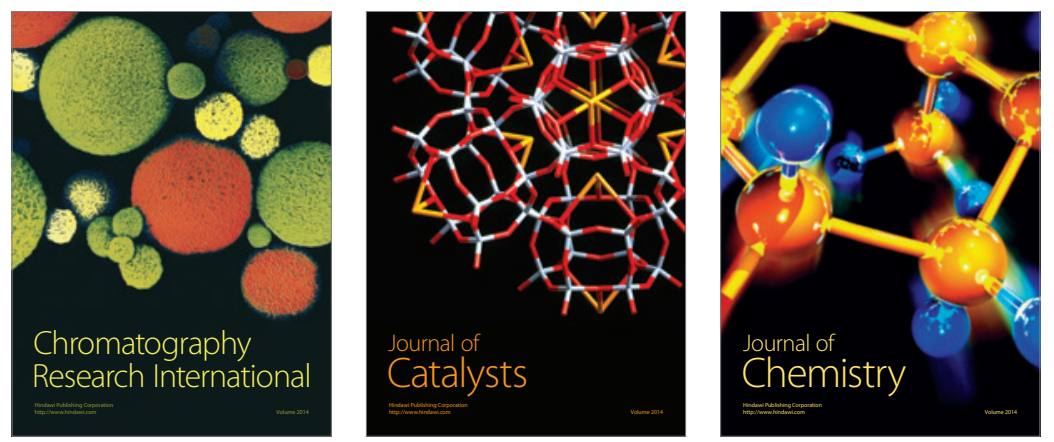
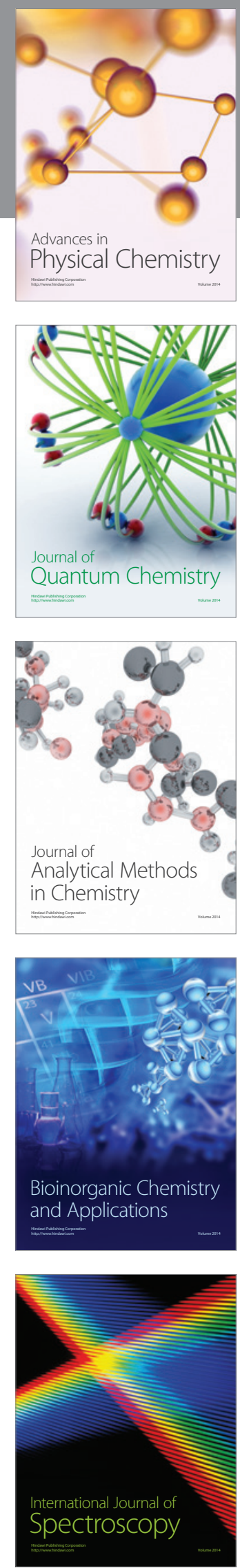